\title{
13 \\ Thinking outside the box: Tobacco plain packaging and the demise of smoking
}

\author{
Becky Freeman ${ }^{1}$
}

\section{Plain packaging and the fight against smoking}

In 2010, Australia was the first nation to announce it would adopt tobacco plain packaging laws. Before this, Australian cigarette packs were required only to include a graphic health warning that covered 30 per cent of the front and 90 per cent of the back of the pack. The remaining 70 per cent of the front of the pack was fully utilised by the tobacco industry to entice new smokers, reassure continuing smokers and promote its brands. Under the new laws, cigarette packs would no longer be permitted to carry any branding or company logos (see Plate 13.1); all tobacco packaging must be a drab dark brown and the cigarette box must be constructed of rigid cardboard with no shiny finishes or any other embellishments. Plain packaging also requires that all packs display a large pictorial health warning on both the front ( 75 per cent of the surface) and the back ( 90 per cent of

\footnotetext{
1 The author does not receive funding from the tobacco industry, the electronic cigarette industry or any affiliated bodies. She has been awarded research grants from the National Health and Medical Research Council of Australia and has undertaken paid consulting work for non-governmental organisations, the World Health Organization and Australian national and state government health departments and has written extensively on the plain packaging policy experience in Australia. Portions of this chapter draw on her previous writing on the subject, including Freeman et al. (2008); Freeman (2011, 2017); Chapman and Freeman (2014); Scollo et al. (2016); and Crosbie et al. (2018).
} 
the surface) and that the product brand and variant name be written in a standard font, size and shade of grey. No company logos, trademarks or brand colours are permitted (Department of Health and Ageing 2012b).

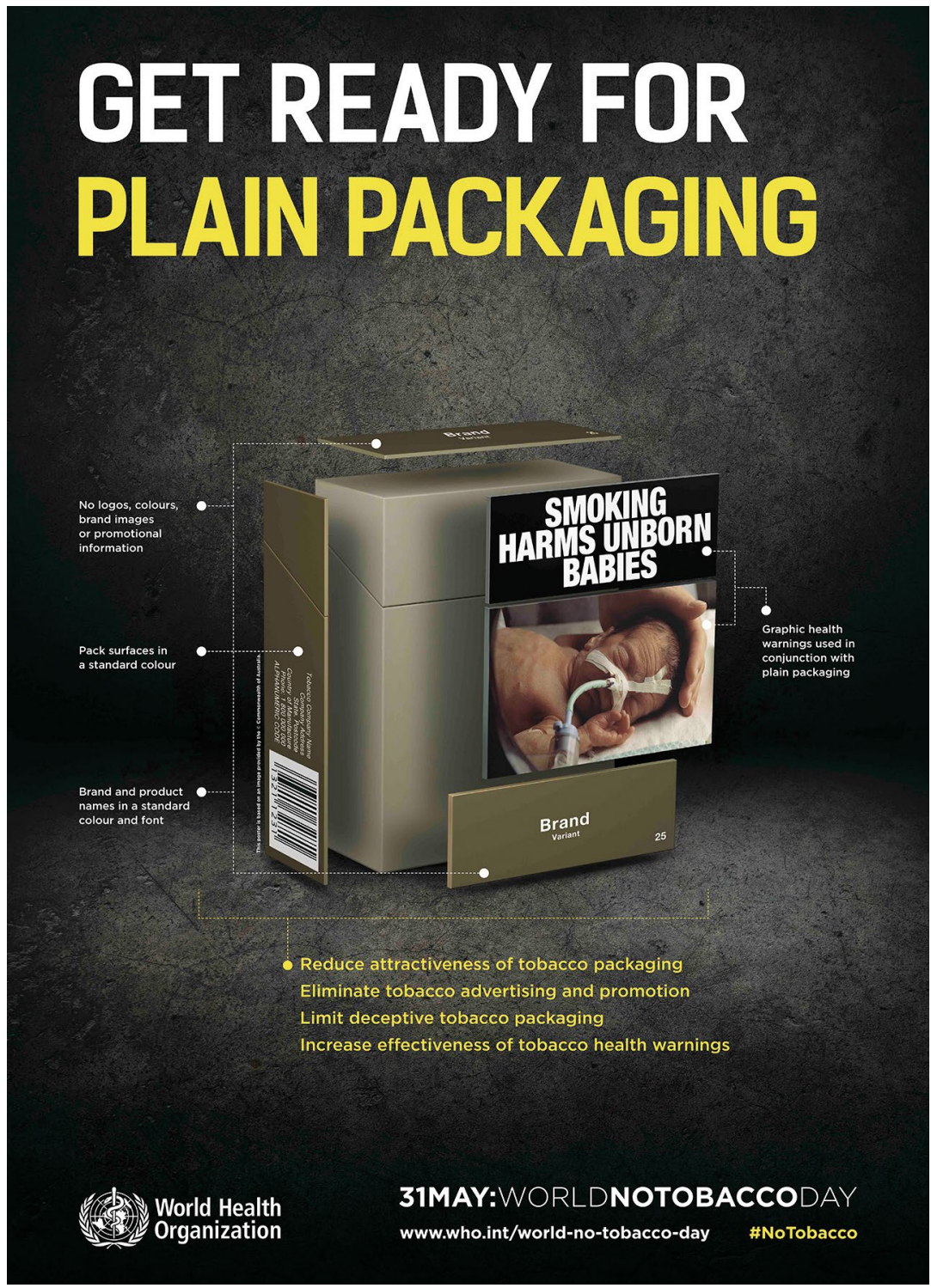

Plate 13.1 The WHO designed this promotional poster, based on Australian plain packaging requirements, for use around the world during the 2016 World No Tobacco Day, on 31 May

Source: WHO (2016). 
Despite attempts from the tobacco industry to thwart this policy by undertaking political lobbying, conducting high-profile media campaigns, hiding behind small retailers and pursuing multiple legal challenges, it is a public health policy success story. Australia has a long history of implementing effective tobacco control policies that have worked together to reduce smoking rates. Plain packaging laws represent the next step in a series of ever tightening regulations that prevent the tobacco industry from promoting its deadly products (Freeman 2017).

Cigarettes, when used exactly as the manufacturers intend, will kill two out of three smokers (Banks et al. 2015). There is simply no other legal product sold openly on the market today that has this same devastating human toll. Policies that can reach whole populations and prevent future smokers from starting, assist those who smoke to quit and not restart and protect people from secondhand smoke are enshrined in the World Health Organization Framework Convention on Tobacco Control (WHO FCTC). Australia, along with 181 other parties, has ratified the WHO FCTC to halt the global tobacco epidemic (WHO 2017a). Plain packaging is just one of a comprehensive suite of policy recommendations contained within that international policy framework and, in the Australian context, it came on the wings of decades of ever-deepening policy interventions designed to arrest smoking (see Table 13.1).

Table 13.1 Tobacco control timeline: Australian policy highlights

\begin{tabular}{|l|l|}
\hline Year & Policy \\
\hline 1973 & Health warnings first mandated on all cigarette packs in Australia. \\
\hline 1976 & Bans on all cigarette advertising on radio and television in Australia. \\
\hline $1986-2006$ & Phasing in of bans on smoking in workplaces and public places. \\
\hline 1990 & $\begin{array}{l}\text { Bans on advertising of tobacco products in newspapers and magazines } \\
\text { published in Australia. }\end{array}$ \\
\hline 1992 & Increase in the tobacco excise. \\
\hline 1993 & $\begin{array}{l}\text { Tobacco Advertising Prohibition Act } 1992 \text { (Cwlth) prohibits broadcasting } \\
\text { and publication of tobacco advertisements. }\end{array}$ \\
\hline $1994-2003$ & Bans on smoking in restaurants. \\
\hline 1995 & Nationally consistent text-only health warnings required on packaging. \\
\hline $1998-2006$ & Bans on point-of-sale tobacco advertising across Australia. \\
\hline 2006 & Graphic health warnings required on packaging of most tobacco products. \\
\hline 2010 & 25 per cent increase in the tobacco excise. \\
\hline
\end{tabular}




\begin{tabular}{|l|l|}
\hline Year & Policy \\
\hline 2011 & $\begin{array}{l}\text { First complete state or territory ban on point-of-sale tobacco } \\
\text { product displays. }\end{array}$ \\
\hline 2012 & $\begin{array}{l}\text { Publishing tobacco advertising on the internet or other electronic media } \\
\text { made an offence. }\end{array}$ \\
\hline 2012 & $\begin{array}{l}\text { Introduction of tobacco plain packaging and updated and expanded } \\
\text { graphic health warnings. }\end{array}$ \\
\hline
\end{tabular}

Source: Department of Health and Ageing (2018).

\section{A policy success}

The adoption of plain packaging laws in Australia is a public health success story. The use of innovative policy measures to reduce the prevalence of smoking and the subsequent health burden is a cornerstone of tobacco control. Plain packaging joins a long list of other successful policy measures, such as bans on tobacco advertising and sponsorship, emotive mass media campaigns urging smokers to quit, high tobacco taxes and smoke-free public places (WHO 2017b). Together, these policies have seen Australia's adult regular smoking rate cut almost in half in less than 20 years-from 27 per cent in 1998 to 14 per cent in 2016 (Greenhalgh and Bayly 2018). Plain packaging stands out as a unique case study on the Australian tobacco control landscape as no other policy was as openly and vociferously attacked by the tobacco industry (Daube et al. 2012). Despite this, it became a policy success.

\section{Programmatic assessment}

The plain packaging measure builds on existing tobacco control policy success that has an overall focus on reducing the demand for tobacco products (Gravely et al. 2017). Reducing the appeal of smoking and tobacco products leads to a reduction in consumer demand and decreased smoking rates. Key demand reduction measures include high tobacco taxes, smoke-free public places, emotive mass media campaigns that warn of the harms of smoking and urge smokers to quit and comprehensive bans on all tobacco advertising, promotion and sponsorship. Additionally, plain packaging increases the size, and refreshes the content, of on-pack graphic health warnings - a policy already proven to be effective. 
One year after the implementation of plain packaging, increased numbers of Australian adult smokers disliked their cigarette pack and perceived it to have lower appeal, lower cigarette quality, lower satisfaction and lower value (Wakefield et al. 2015). Increased numbers of smokers also no longer believed that brands differed in terms of prestige. More adult smokers also noticed the new and larger graphic health warnings, attributed motivation to quit to the warnings, avoided specific warnings when purchasing a pack and covered up their packs. Similarly, among Australian adolescents who had seen a cigarette pack in the previous six months, the appeal of cigarette packs and brands had decreased and there was a large increase in the proportion disagreeing that some brands had better-looking packs than others (White et al. 2015).

There is also evidence that the larger health warnings and plain packaging reforms had an impact on adult smokers' quitting behaviours (Young et al. 2014; Durkin et al. 2015). There was a 78 per cent increase in the number of calls to the Quitline (a toll-free, telephone-based smoking cessation counselling service) with the introduction of plain packaging, which peaked four weeks after plain packs initially appeared for sale at retail outlets (Young et al. 2014). This increased call rate was sustained for 43 weeks. In a study comparing a series of smoker cohorts who were surveyed about quitting behaviours before, during the transition period of plain packs coming on to the market and one year after implementation, there were significantly greater increases in rates of attempts to quit in the transition period and one year after compared with the period before plain packaging (Durkin et al. 2015).

The incidence of smoking is significantly higher among lower socioeconomic groups, and even more so in groups facing multiple personal and social disadvantages. Smoking is one of the major factors driving poorer health status in economically disadvantaged areas and groups (Greenhalgh and Scollo 2018). Policies that reduce smoking have significant potential to reduce inequalities, provided the positive effects are experienced across the population. Overall, the absolute gap in smoking prevalence between the most and least disadvantaged Australians has stayed fairly constant for the decade 2004-13, at about 14 per cent, before narrowing to about 12 per cent in 2016. Encouragingly, smoking rates have reduced among Australian school students across all socioeconomic groups, and generally there is very little difference in smoking status among socioeconomic groups during childhood (Greenhalgh and Scollo 2018). 
The costs of the policy are borne almost entirely by the tobacco industry itself. While the Australian Government has had to contribute significant funds to defending the policy from three separate cases of legal action by the tobacco industry, these costs have been offset, as the industry was required to pay some of these costs (Gartrell 2017).

\section{Process assessment}

The recommendation that tobacco products be sold in standardised packaging, without any branding, had a firm evidence base. It was presented as part of a comprehensive set of public health policy recommendations made by an independent expert body. This body, the Preventative Health Taskforce, was established in 2008 by then health minister Nicola Roxon. The taskforce released a draft report for public consultation and comment in October 2008 (Moodie et al. 2008), with more than 400 submissions received. A final report was issued to government in June 2009 and, two months later, released publicly (National Preventative Health Taskforce 2009). The report describes plain packaging as a policy that

would prohibit brand imagery, colours, corporate logos and trademarks, permitting manufacturers only to print the brand name in a mandated size, font and place, in addition to required health warnings and other legally mandated product information such as toxic constituents, taxpaid seals or package contents. A standard cardboard texture would be mandatory, and the size and shape of the package and cellophane wrapper would also be prescribed. A detailed analysis of current marketing practices suggests that plain packaging would also need to encompass pack interiors and the cigarette itself, given the potential for manufacturers to use colours, bandings and markings, and different length and gauges to make cigarettes more 'interesting' and appealing. Any use of perfuming, incorporation of audio chips or affixing of 'onserts' would also need to be banned. (National Preventative Health Taskforce 2009: 181)

\section{Political assessment}

Unlike some other areas of public health reform, tobacco control has greatly benefited by attracting support from across the major political parties in Australia. While the plain packaging legislation was led by Labor, the Liberal Party (the official opposition at the time, led by Tony Abbott) — after some initial 'dithering' (Grattan 2011)—did not oppose the legislation and eventually came to enthusiastically support it, ensuring it was easily passed through parliament. 
Civil society engagement and advocacy for plain packaging were exceptionally high. High-profile health groups-such as the Cancer Council Australia, the Heart Foundation, VicHealth, the Public Health Association, Action on Smoking and Health, the Australian Council on Smoking and Health and the Australian Medical Association (AMA) and high-profile public health, medical and legal academics contributed to the advocacy efforts. These public agencies and figures were positioned as being credible and trustworthy opponents of an industry riddled with reputational issues.

The Liberal Party feared that if it decided to not support the plain packaging reforms, this could damage its reputation-especially given the high profile and influence of the health groups that had thrown their support behind the reforms (Chapman and Freeman 2014). Siding with the tobacco industry - the most visible and vocal opponent of the reforms - would be likened to siding with the merchants of death. Few politicians want to be seen as being in partnership with an industry that is known for overtly lying about the addictiveness and harmfulness of its products (Chapman and Freeman 2008). A 2011 opinion poll showed the majority of Australians also supported the policy (Cancer Council Australia 2011), which served to reassure policymakers that adopting the reforms would enhance their political capital.

\section{The genesis of plain packaging}

Globally, tobacco use is one of the leading preventable causes of early death and disease. Prevention of tobacco uptake and addiction is a cornerstone of tobacco control. Most people start smoking when they are teenagers or very young adults. The key influences on young people taking up smoking are the advertising and promotion of tobacco products. This is despite the fact the tobacco industry has always claimed that it has no interest whatsoever in attracting new, non-smoking youth customers but is interested only in stimulating brand-switching and maintaining brand loyalty among current adult smokers. While Australia long ago banned most overt forms of tobacco promotion, arguably the most effective and personal form of promotion, the tobacco package itself, had been left largely untouched. 
Packaging design is a major way of differentiating and promoting brands and is particularly important in homogeneous consumer products such as cigarettes, for which—like bottled water, for example-few objective differences exist between brands. Marketing literature routinely highlights the critical role played by package design in the overall marketing mix, emphasising that the 'product package is the communication life-blood of the firm', the 'silent salesman' that reaches out to customers and that packaging acts 'as a promotional tool in its own right' (Freeman et al. 2008). The other important goal of packaging design that is unique to tobacco products is the use of the package to obscure, downplay and minimise government-mandated health warnings that compel smokers to quit.

\section{Australian context}

Australia has long been a leader in advocating and implementing tobacco control legislation (Chapman and Wakefield 2001; Scollo 2012). Prior to the implementation of plain packaging laws, tobacco packages sold in Australia featured graphic health warnings and could not be visible at retail outlets where they were sold. Tobacco products could not be advertised or promoted to the public, including through event sponsorship. Tobacco products were highly taxed and emotive campaigns compelled smokers to quit. Communities and politicians of all stripes welcomed laws that banned smoking inside all public places, workplaces, licensed premises and many outdoors areas. This set the scene for both political and public acceptance of the seemingly radical policy to completely remove all branding imagery from tobacco packages. Plain packaging was the next step in implementing a comprehensive approach to tobacco control and Australia was ideally suited to be the first nation to implement the innovative policy (Freeman 2017).

At the time plain packaging was announced, Australia's regular smoking rate ('regular' is defined as smoking at least weekly) among adults aged over 18 years was 18 per cent. This was about half the rate of 1980 , when it was about 35 per cent. The latest available national survey data (at the time of writing), from 2016, put this regular smoking prevalence at a low of 13 per cent (Greenhalgh et al. 2018). This is a rate comparable with other high-income countries with a history of implementing tobacco control measures, such as Sweden, Canada, Iceland and Norway. Australia's low smoking rate is attributable to 'concerted, sustained, and comprehensive public policy efforts from all levels of government and action from public health organisations' (Department of Health and Ageing 2018). 


\section{Plain packaging: A brief history}

While plain packaging laws were first implemented in Australia in 2012, initial discussions about this policy reform among health and medical professionals and tobacco control researchers can be traced back to Canada in the mid-1980s. In 1995, a Canadian parliamentary committee endorsed plain packaging as a government policy, but legal challenges to existing Canadian tobacco control laws, changes in health ministers and intense tobacco industry lobbying meant the issue lost momentum in that country (Freeman 2017). In 2000, Canada did pave the way for governments to acquire significant control of the appearance of tobacco packaging, by becoming the first country to require large, full-colour, graphic health warnings on all tobacco packages. While other countries, including Australia, moved to follow Canada's lead on requiring large graphic warnings on packs, plain packaging reforms were largely left aside, and no significant policy progress was made to remove branding elements from packaging (Chapman and Freeman 2014). Following Australia's success, Canada is now poised to adopt even more advanced plain packaging requirements, with the release of draft regulations in June 2018. The proposed regulations extend to standardising the size and appearance of cigarettes themselves and mandating that the graphic health warnings take up more surface area on the pack than in any other country in the world (Canadian Cancer Society 2018a).

In 1992 in Australia, the Australian Ministerial Council on Drug Strategy proposed large new warnings for all tobacco packages and requested a report on plain packaging. In 1995, however, the Australian Senate's Community Affairs Reference Committee (Parliament of Australia 1995) released a lengthy report that concluded that, 'on the basis of the evidence received, there is not sufficient evidence to recommend that tobacco products be sold in generic packaging'. Belatedly, in 1997, the Australian Government replied to the committee's report:

In response to the mounting interest in generic packaging, the Commonwealth obtained advice from the Attorney-General's Department on the legal and constitutional barriers to generic packaging. This advice indicates that the Commonwealth does possess powers under the Constitution to introduce such packaging but that any attempt to use these powers to introduce further tobacco control legislation needs to be considered in the context of the increasingly critical attention being focussed on the necessity, appropriateness, justification and basis for 
regulation by such bodies as the Office of Regulatory Review, the High Court, and Senate Standing Committees. In addition, further regulation needs to be considered in the context of Australia's international obligations regarding free trade under the General Agreement on Tariff[s] and Trade (GATT), and our obligations under international covenants such as the Paris Convention for the Protection of Industrial Property, and the Agreement on Trade-Related Aspects of Intellectual Property Rights (TRIPS). (Department of Health 1997: 30)

More than 13 years later, and these same arguments - that plain packaging was both a free-trade violation and counter to the protection of intellectual property rights — would once again be espoused by the tobacco industry and its lobby groups. However, this time, under the leadership of Roxon, a health minister trained as a lawyer, who knew these arguments did not hold water, the Australian Government was not so easily intimidated by the legal sabre rattling.

\section{Drivers and stewards}

As mentioned, in April 2008, the recently elected Labor Government established the National Preventative Health Taskforce to develop policy and program recommendations with a focus on three priority areas: tobacco, alcohol and obesity. A group of experts was convened for each priority area and prepared a discussion paper and final report to help inform government policy action.

The discussion paper on tobacco included a wide range of policy initiatives, including plain packaging. Following the release of the paper, there was an extensive period-until April 2009-for consultation and public submissions. The taskforce's final report, delivered to the health minister on 30 June 2009 and subsequently released on 1 September 2009, recommended plain packaging as part of a comprehensive approach:

Mandate standard plain packaging of all tobacco products to ensure that design features of the pack in no way reduce the prominence or impact or prescribed government warnings the pack. (Tobacco Working Group 2009: VII)

Nearly eight months passed until 29 April 2010, when prime minister Kevin Rudd and Roxon announced that Australia would mandate plain packaging from July 2012. The policy was finally fully enacted in December 2012. Table 13.2 outlines the major policy milestones that occurred between the April announcement and the Bill being passed into law. 
Table 13.2 Timeline of major milestones in the development of the tobacco plain packaging legislation

\begin{tabular}{|c|c|}
\hline Date & Milestone \\
\hline 9 April 2008 & $\begin{array}{l}\text { Health minister Nicola Roxon announces establishment of the } \\
\text { National Preventative Health Taskforce. }\end{array}$ \\
\hline 10 October 2008 & $\begin{array}{l}\text { Release for consultation of the draft report of the Preventative } \\
\text { Health Taskforce, entitled Australia: The healthiest country by } \\
\text { 2020, which contained a large number of recommendations, } \\
\text { including one concerning plain packaging of tobacco products. }\end{array}$ \\
\hline 15 April 2009 & $\begin{array}{l}\text { National Preventative Health Taskforce announces it has } \\
\text { considered more than } 400 \text { submissions received on its draft } \\
\text { report released in October } 2008 \text {. }\end{array}$ \\
\hline 30 June 2009 & $\begin{array}{l}\text { National Preventative Health Taskforce provides final report, } \\
\text { entitled National Preventative Health Strategy: The roadmap for } \\
\text { action, to the government for consideration. }\end{array}$ \\
\hline 1 September 2009 & $\begin{array}{l}\text { Minister Roxon releases the final report of the Preventative Health } \\
\text { Taskforce, which recommends plain packaging as part of a } \\
\text { comprehensive suite of measures to make Australia the healthiest } \\
\text { country in the world by } 2020 \text {. }\end{array}$ \\
\hline 29 April 2010 & $\begin{array}{l}\text { The Australian Government announces its decision to implement } \\
\text { plain packaging for tobacco products and to mandate updated } \\
\text { and expanded graphic health warnings. }\end{array}$ \\
\hline 7 April 2011 & $\begin{array}{l}\text { The Australian Government releases an exposure draft of the } \\
\text { legislation alongside a consultation paper, with comments to be } \\
\text { received within the following } 60 \text { days. }\end{array}$ \\
\hline 31 May 2011 & The Opposition announces it will not oppose plain packaging. \\
\hline 6 June 2011 & $\begin{array}{l}\text { The government receives over } 250 \text { submissions on the draft plain } \\
\text { packaging legislation. }\end{array}$ \\
\hline 6 July 2011 & $\begin{array}{l}\text { Plain packaging Bill introduced into the House of } \\
\text { Representatives, first and second reading moved. }\end{array}$ \\
\hline 7 July 2011 & $\begin{array}{l}\text { House of Representatives refers Bill to Standing Committee } \\
\text { on Health and Aged Care. }\end{array}$ \\
\hline 22 August 2011 & $\begin{array}{l}\text { House of Representatives Standing Committee on Health and } \\
\text { Aged Care tables the report on its inquiry into tobacco plain } \\
\text { packaging. }\end{array}$ \\
\hline 24 August 2011 & $\begin{array}{l}\text { Second reading debate; third reading agreed to passage } \\
\text { of legislation through House of Representatives. }\end{array}$ \\
\hline 25 August 2011 & $\begin{array}{l}\text { Bill introduced and read a first time in Senate; second reading } \\
\text { moved. }\end{array}$ \\
\hline 11 October 2011 & Second reading debate in Senate commences. \\
\hline 2 November 2011 & $\begin{array}{l}\text { Minister Roxon announces the implementation of plain packaging } \\
\text { will be delayed until } 1 \text { December } 2012 \text { as a result of delays in the } \\
\text { Senate's review of the Bill. }\end{array}$ \\
\hline
\end{tabular}




\begin{tabular}{|l|l|}
\hline Date & Milestone \\
\hline $\begin{array}{l}\text { 9-10 November } \\
\text { 211 November 2011 }\end{array}$ & $\begin{array}{l}\text { Bill returns to Senate, including revised timelines. Second reading } \\
\text { debate continues; second reading agreed to; third reading } \\
\text { agreed to. }\end{array}$ \\
\hline $\begin{array}{l}\text { Final passage of amended Tobacco Plain Packaging Bill through } \\
\text { House of Representatives. Vote on Tobacco Plain Packaging } \\
\text { Bill as amended by the Senate. The Bill passes the Australian } \\
\text { Parliament, including amendments to extend the time frame for } \\
\text { implementation (Parliament of Australia 2011). }\end{array}$ \\
\hline 1 December 2011 & $\begin{array}{l}\text { Governor-General signs Tobacco Plain Packaging Act 2011 } \\
\text { into law. }\end{array}$ \\
\hline October 2012 & Some packs with plain packaging start to appear in retail outlets. \\
\hline 1 December 2012 & $\begin{array}{l}\text { From this date, all tobacco packages in Australia must appear } \\
\text { in plain packaging, as specified in the Tobacco Plain Packaging } \\
\text { Act 2011. }\end{array}$ \\
\hline
\end{tabular}

The pushback from the tobacco industry and its allies was strong and immediate (Kelly et al. 2011). The tobacco industry has a long and consistent history of fighting the adoption of policies that reduce both the demand for tobacco products and the social acceptability of smoking (Chapman and Carter 2003). On the surface, plain packaging could be seen as just the next in a very long line of measures the tobacco industry has railed against in an effort to maintain tobacco use and sales. However, in the years preceding the plain packaging announcement, the Australian tobacco industry had largely stepped back from directly commenting on and campaigning publicly against changes to Australian tobacco control policy (Cadzow 2008; McLeod et al. 2009). The planned plain packaging laws marked a dramatic change in the tobacco industry's tactics and saw it not only actively appearing in news articles and programs, but also launching its own paid media campaigns.

For example, in August 2010, the Alliance of Australian Retailers (AAR) launched national advertisements online, in newspapers and on television and radio featuring actors portraying concerned retailers who said plain packaging would not work and would damage their businesses. ${ }^{2}$ Following this high-profile media campaign, an Australian investigative news program revealed the extent of tobacco industry involvement in the formation and funding of the AAR. On the day the AAR was formed, it received funds from the three main tobacco companies operating in

2 The AAR ads can be viewed here: www.youtube.com/user/analogcreative/videos? view=0. 
Australia, Imperial Tobacco Australia ( $\$ 1$ million), British American Tobacco Australia (\$2.2 million) and Philip Morris (\$2.1 million) (Scollo et al. 2016).

The AAR campaign appeared to backfire. A survey of 2,101 Victorians found it failed to persuade people that plain packaging would not be effective, with 86.2 per cent saying it made no difference to their views about plain packaging and 8.4 per cent of respondents claiming the advertisement actually increased their support for plain packaging reforms (Quit Victoria 2011).

The degree to which the tobacco industry protested against plain packaging suggests the public health community was on to a policy that would really impact its profitability. A key counter-lobbying strategy was addressing the 'plain packaging won't work' argument through research evidence gathered, synthesised and then disseminated through countless news articles and interviews, opinion pieces, blog posts and social media posts. The Cancer Council Victoria and Quit Victoria-Australian nongovernmental agencies-prepared a comprehensive electronic evidence review of plain packaging. The review summarised all of the 25 published experimental studies that examined the likely impact of plain packaging on young people and current smokers. The primary finding of these studies was that adults and adolescents perceived cigarettes in plain packages to be less appealing, less palatable, less satisfying and of lower quality compared with cigarettes in existing packaging. Plain packaging would also affect young people's perceptions of the characteristics and status of the people who smoked particular brands.

\section{Policy design and choice}

In a demonstration of unwavering political commitment to the Preventative Health Taskforce process, on 29 April 2010, Roxon and Rudd announced that Australia would be the first country to adopt plain packaging laws, with an anticipated implementation date of July 2012 (implementation was subsequently delayed until December 2012). Funding was committed for both the expected tobacco industry legal challenges and an extensive evaluation of the policy. The effort and deduction of the public servants tasked with progressing tobacco plain packaging into law were recognised at the 2012 World Conference on 
Tobacco or Health, in Singapore, when the Australian health department was awarded the American Cancer Society's Luther L. Terry Award for outstanding leadership by a government ministry.

Tobacco plain packaging was primarily framed as a protective measure aimed at preventing young people from taking up tobacco use. Preventing young people from ever starting smoking is an investment that reaps rewards in the future in terms of reduced disease burden and mortality from tobacco use. The highly addictive nature of tobacco products means that youth experimentation with smoking can lead to a lifelong addiction that some smokers find incredibly difficult to break. Very few people start smoking beyond adolescence and early adulthood and there is near universal regret among established smokers about ever having started.

The final agreed design of plain packaging was a result of extensive consumer testing and consultation. The dark brown colour was chosen as consumers found

this colour to be less appealing, to contain cigarettes that were perceived to be more harmful to health, of lower quality, and to make it harder to quit smoking. Additionally, this colour was not at all similar to any existing cigarette brand and failed to generate any positive associations for consumers. (GfK Blue Moon 2011)

The goals of the plain packaging law were clearly and purposefully developed to ensure they could be readily and transparently evaluated. Specifically, plain packaging was designed to:

- reduce the appeal of tobacco products to consumers

- increase the effectiveness of health warnings

- reduce the ability of the retail packaging of tobacco products to mislead consumers about the harmful effects of smoking or using tobacco products (Department of Health and Ageing 2012a).

The costs associated with the plain packaging policy are largely borne by the tobacco industry. Apart from the initial costs of preparing the legislation and defending it in legal proceedings, there are limited ongoing costs for the government. Additionally, in terms of unintended consequences, many of the negative arguments raised against the implementation of plain packaging never came to fruition. Indeed, one unintended immediate positive outcome appeared to be that smokers 
perceived their plainly packaged cigarettes as tasting terrible and went so far as accusing the government of reformulating cigarettes alongside the packaging (Siegel 2013).

An essential public health policy message is that plain packaging is just one part of Australia's successful approach to tobacco control. Plain packaging laws are likely to be most effective when accompanied by large graphic health warnings and implemented as part of a comprehensive smoking prevention and cessation strategy. Plain packaging was not implemented in isolation. The same day the reforms were announced, an immediate tobacco tax increase of 25 per cent was also adoptedthe first real tobacco tax increase beyond the consumer price index since 1999. Tobacco taxes are the most effective and necessary policy tool for reducing smoking rates, but are further enhanced by support services, social marketing campaigns and policy changes that reduce the appeal of smoking. It is estimated a 10 per cent increase in tobacco prices will be followed by a decrease in tobacco consumption of about 4.8 per cent (Gallet and List 2003).

So far in the history of tobacco control, there is no single magic policy approach to make smoking rates plummet overnight; reductions are incremental and occur slowly as a result of prolonged investment in public health measures and increasingly strict regulation.

\section{Delivery, legitimacy and endurance}

It was fully expected that the tobacco industry would issue legal challenges to plain packaging laws and initial arguments opposed to plain packaging questioned whether the Australian Government could enact such a law. Fortunately, the government was well prepared for and resourced to take on these legal challenges. The industry launched three separate legal challenges: first, to the Australian domestic courts (Liberman 2013); second, through an investment treaty with Hong Kong; and third, by supporting four countries-Cuba, Honduras, Indonesia and the Dominican Republic - to file disputes through the World Trade Organization (Voon and Mitchell 2011). All three challenges were resolved in Australia's favour and, in the case of the first two disputes, the industry was ordered to pay the government's legal costs. 
There are no 'win-win' solutions in tobacco control that see both public health and the tobacco industry benefit. A common barometer known as the 'scream test' measures how likely it is a tobacco control policy will succeed by how loudly the tobacco industry opposes it (McKee 2017). When public health measures are adopted, the tobacco industry must fail. The WHO FCTC embodies this principle in Article 5.3, which states:

In setting and implementing their public health policies with respect to tobacco control, Parties shall act to protect these policies from commercial and other vested interests of the tobacco industry in accordance with national law. (WHO 2005)

Extensive independent research and evaluation have shown plain packaging was, and remains, successful as measured against its stated objectives. In December 2014, the Department of Health commenced a post-implementation review of plain packaging. The body of studies included in the review demonstrated the tobacco plain packaging measures had an impact by reducing the appeal of tobacco products, increasing the effectiveness of health warnings and reducing the ability of the packaging to mislead smokers. The studies also provided early evidence of positive changes to smoking and quitting behaviours (Department of Health 2018).

The primary beneficiaries of the plain packaging policy are those who quit smoking and the children who are prevented from ever taking up smoking. It is estimated that the packaging changes resulted in a 0.55 per cent decline in Australia's smoking prevalence-equivalent to 108,228 fewer smokers-between December 2012 and September 2015. The policymakers and stakeholders who supported and drove the implementation of plain packaging have also benefited. International accolades and awards have been bestowed on Nicola Roxon and the Australian health department alike. Additionally, and perhaps most substantially, Australia has paved the way for other nations to adopt similar measures.

Since Australia first implemented plain packaging, there has been an international movement to make this policy a global standard in the fight against tobacco-related deaths. Plain packaging has been adopted in nine countries and is under consideration in at least 16 other jurisdictions (Canadian Cancer Society 2018b). Plain packaging has been implemented in France (in 2016), the United Kingdom (2016), Norway (2017), Ireland (2017), New Zealand (2018) and Hungary (2018); it will 
be implemented in Uruguay (in 2019) and Slovenia (2020) and is in process or under consideration in Canada, Belgium, Thailand, Georgia, Singapore, Nepal, Sri Lanka, South Africa, Romania, Jersey, Guernsey, Taiwan, Chile, Finland and Saudi Arabia. The governments of Mauritius, Kenya, Gambia, Botswana and Burkina Faso have also expressed support for implementation of plain packaging. As has happened with other successful tobacco control policies, momentum appears to be continuing to build and this list will grow longer each year.

The primary 'loser' in the plain packaging saga is the tobacco industry itself. In Australia, tobacco is no longer grown or manufactured so there is no 'homegrown' industry that requires transition assistance as smoking rates decline. All three major tobacco companies that operate in Australia are wholly owned subsidiaries of overseas parent companies. Despite launching the three separate legal challenges to the policy, the industry has not been successful in overturning the law nor has it been compensated for any financial or intellectual property losses as a result of the legislation. The industry suffered further loss to its already slim credibility when it was revealed that a media campaign against plain packaging-which was supposedly being led by small Australian retailers-was in fact fully funded by three international tobacco companies, as previously discussed.

\section{Analysis and conclusions}

The single biggest hurdle to the success of plain packaging was essentially a question of timing. While tobacco control advocates and the tobacco industry itself long recognised that the packages were powerful advertisements and inducements to smoke, it took decades from when the idea was first mooted until the right conditions converged to allow such a 'radical' idea to become law. The election of a government that recognised that taking on the tobacco industry was both legally possible and politically desirable created an opportunity to push through a policy that was previously considered too extreme. A short six years later and plain packaging is no longer on the fringes of acceptable public health actions but is a standard that has been set for other nations equally concerned about tobacco use.

Nicola Roxon has emphasised several factors as key drivers of the tobacco plain packaging success, including: the strong evidence base, the reputation and coherence of the tobacco control community and the 
high level of expertise in the public service, legal profession and public health sphere (Chapman and Freeman 2014). In turn, Roxon's role as political champion is cited as being critical to moving plain packaging from a recommendation in yet another government report to a concrete action enshrined in law. The public acceptance of plain packaging laws is reflective of decades of work that have seen smoking, and the tobacco industry, move from socially desirable and acceptable to a behaviour and an industry that conjure images of death, disease and deceit. There are no negative consequences to taking on an industry that lacks genuine allies; many of its best customers are feeling hooked rather than enthused. Tobacco control advocates have been highly successful in developing the dominant frame that equates the tobacco industry with corporate malfeasance. There is no government reputational loss or genuine threat to policy success when the only opposition is best known for preying on vulnerable children and addicting them to deadly products.

Unlike some other areas of public health, where policy goals are perhaps more complex and nuanced, tobacco control goals have long been clear and consistent: reduce the number of people who take up smoking, help those who already smoke to quit and protect non-smokers from harmful secondhand smoke. Equally, the unequivocal exclusion of the tobacco industry as a partner in developing policies that achieve these goals is unique. In other areas of public health reform—such as alcohol, gambling and food-there is a struggle to disentangle the powerful commercial influences from the policymaking process. As a result, policies that are meant to improve public health are often ineffective as they do little to impede the marketing and sales success of the products and companies that harm public health. These industries have observed how the exclusion of the tobacco industry from the policymaking table has made it easier to advance public health and have taken steps to safeguard their interests (Kickbusch et al. 2016).

There is little concern that plain packaging legislation-having survived legal challenges and undergone extensive evaluation-will be overturned. Other jurisdictions have taken steps to strengthen their plain packaging laws, including increasing the size of the health warning and applying more stringent measures to the size and shape of the cigarettes themselves (Canadian Cancer Society 2018b). A possible future threat to the success of the policy - and tobacco control in general-is a well-funded and determined tobacco industry that is attempting to rebrand itself as a good corporate citizen with new 'harm reduction' products. Launched 
in 2017, the Philip Morris International Foundation for a Smokefree World, headed by former WHO senior executive Derek Yach, is part of a portfolio of public relations initiatives to supposedly rehabilitate the industry (Foundation for a Smoke-Free World 2018). It is also naive to assume that plain packaging will bring an end to tobacco marketing. Tobacco companies still rely heavily on their relationships with retailers to ensure their brands are readily available to consumers, are positioned as market leaders and are sold alongside other everyday items. Tobacco marketing remains largely unregulated and allows the tobacco industry to offer retailers incentives and discounts to push its brands to consumers (Freeman 2017).

When reflecting on what additional potential lessons for policy design, political management and policy leadership might be drawn from this case that could aid in this success being replicated, the importance of structural factors becomes clear. A strong and united tobacco control workforce that is truly multidisciplinary proved crucial. This workforce took decades to build, mirroring the time it took for plain packaging to be adopted. While earlier tobacco efforts involved only a small number of outspoken advocates, tobacco control is now an established field that draws expertise from the legal profession, economists, the public service, politicians and political advisors, academia, civil society, human rights movements, social service organisations and even high-profile philanthropists such as Bill and Melinda Gates and Michael Bloomberg.

The commitment of resources-both human and financial-globally, nationally and locally has given not only stability within the Australian tobacco control workforce, but also tacit approval of its principles and ideas. This 'mainstreaming' of public health activism served to legitimise tobacco control and, in turn, plain packaging. The professionalisation of tobacco control through research, training and expansion beyond public health programs positions its policy reforms and goals as valid priorities for action. 


\section{References}

Banks, E., Joshy, G., Weber, M. F., Liu, B., Grenfell, R., Egger, S., Paige, E., Lopez, A. D., Sitas, F. and Beral, V. 2015. 'Tobacco smoking and all-cause mortality in a large Australian cohort study: Findings from a mature epidemic with current low smoking prevalence.' BMC Medicine 13: 38. doi.org/ 10.1186/s12916-015-0281-z.

Cadzow, J. 2008. 'Hi ho hi ho it's off to work we go.' [Good Weekend], Sydney Morning Herald, 27 September.

Canadian Cancer Society 2018a. Canada to have the world's best tobacco plain packaging requirements. Press release. Ottawa: Canadian Cancer Society. Available from: www.cancer.ca/en/about-us/for-media/media-releases/national/ 2018/canadian-plain-packaging-requirements/?region=on.

Canadian Cancer Society 2018b. Cigarette Package Health Warnings: International status report. 6th edn. Ottawa: Canadian Cancer Society. Available from: www. cancer.ca/ / media/cancer.ca/CW/for\%20media/Media\%20releases/2018/ CCS-international-warnings-report-2018---English---2-MB.pdf?la=fr-CA.

Cancer Council Australia 2011. Plain tobacco packaging a winner with Australians: New poll. Media release, 29 May. Sydney: Cancer Council Australia. Available from: www.cancer.org.au/news/media-releases/mediareleases-2011/plain-tobacco-packaging-a-winner-with-australians-new-poll. html.

Chapman, S. and Carter, S. 2003. '“Avoid health warnings on all tobacco products for just as long as we can": A history of Australian tobacco industry efforts to avoid, delay and dilute health warnings on cigarettes.' Tobacco Control 12: S13-S22. doi.org/10.1136/tc.12.suppl_3.iii13.

Chapman, S. and Freeman, B. 2008. 'Markers of the denormalisation of smoking and the tobacco industry.' Tobacco Control 17: 25-31. doi.org/10.1136/tc. 2007.021386.

Chapman, S. and Freeman, B. 2014. Removing the Emperor's Clothes: Australia and tobacco plain packaging. Sydney: Sydney University Press.

Chapman, S. and Wakefield, M. 2001. 'Tobacco control advocacy in Australia: Reflections on 30 years of progress.' Health Education \& Behavior 28: 274-89. doi.org/10.1177/109019810102800303. 
Crosbie, E., Thomson, G., Freeman, B. and Bialous, S. 2018. 'Advancing progressive health policy to reduce NCDs amidst international commercial opposition: Tobacco standardised packaging in Australia.' Global Public Health 13(12)(December): 1753-66. doi.org/10.1080/17441692.2018.1443485.

Daube, M., Moodie, A. R. and Chapman, S. 2012. 'Plain packaging of tobacco products: Plainly a success.' Medical Journal of Australia 197: 537-8. doi.org/ $10.5694 / \mathrm{mja} 12.11612$.

Department of Health 1997. Government Response to the Report of the Senate Community Affairs Reference Committee: The tobacco industry and the costs of tobacco-related illness. September. Canberra: Commonwealth of Australia.

Department of Health 2018. Evaluation of Tobacco Plain Packaging in Australia. Canberra: Commonwealth of Australia. Available from: www.health.gov.au/ internet/main/publishing.nsf/content/tobacco-plain-packaging-evaluation.

Department of Health and Ageing 2012a. Introduction of Tobacco Plain Packaging in Australia. Canberra: Commonwealth of Australia. Available from: www. health.gov.au/internet/main/publishing.nsf/content/tobacco-plain.

Department of Health and Ageing 2012b. Tobacco Plain Packaging: Your guide. Canberra: Commonwealth of Australia. Available from: health.gov.au/ internet/main/publishing.nsf/Content/tppbook.

Department of Health and Ageing 2018. 'Tobacco control timeline.' In Tobacco Control Key Facts and Figures. Canberra: Commonwealth of Australia. Available from: www.health.gov.au/internet/publications/publishing.nsf/ Content/tobacco-control-toc - timeline.

Durkin, S., Brennan, E., Coomber, K., Zacher, M., Scollo, M. and Wakefield, M. 2015. 'Short-term changes in quitting-related cognitions and behaviours after the implementation of plain packaging with larger health warnings: Findings from a national cohort study with Australian adult smokers.' Tobacco Control 24: ii26-ii32. doi.org/10.1136/tobaccocontrol-2014-052058.

Foundation for a Smoke-Free World 2018. Website. Available from: www.smoke freeworld.org/.

Freeman, B. 2011. 'Tobacco plain packaging legislation: A content analysis of commentary posted on Australian online news.' Tobacco Control 20(5): 361-6.

Freeman, B. 2017. 'Making the case for Canada to join the tobacco plain packaging revolution.' QUT Law Review 17: 83-101. doi.org/10.5204/qutlr. v17i2.703. 
Freeman, B., Chapman, S. and Rimmer, M. 2008. 'The case for the plain packaging of tobacco products.' Addiction 103: 580-90. doi.org/10.1111/ j.1360-0443.2008.02145.x.

Gallet, C. A. and List, J. A. 2003. 'Cigarette demand: A meta-analysis of elasticities.' Health Economics 12: 821-35. doi.org/10.1002/hec.765.

Gartrell, A. 2017. 'Philip Morris ordered to pay Australia millions in costs for plain packaging case.' Sydney Morning Herald, 9 July. Available from: www.smh.com.au/politics/federal/philip-morris-ordered-to-pay-australiamillions-in-costs-for-plain-packaging-case-20170709-gx7mv5.html.

GfK Blue Moon 2011. Market research to determine effective plain packaging of tobacco products. Media release. Sydney: GfK Blue Moon. Accessed from: www.yourhealth.gov.au/internet/yourhealth/publishing.nsf/content/8B0333 A18648BCF3CA25796E0023D826/\$File/Market\%20Research\%20-\%20 Plain\%20Packaging\%20of\%20Tobacco\%20Products.pdf (site discontinued).

Grattan, M. 2011. 'Leadership lacking as Libs squabble over smoking.' Sydney Morning Herald, 27 May. Available from: www.smh.com.au/politics/federal/ leadership-lacking-as-libs-squabble-over-smoking-20110526-1f693.html.

Gravely, S., Giovino, G. A., Craig, L., Commar, A., D'espaignet, E. T., Schotte, K. and Fong, G. T. 2017. 'Implementation of key demand-reduction measures of the WHO Framework Convention on Tobacco Control and change in smoking prevalence in 126 countries: An association study.' The Lancet Public Health 2: e166-e174. doi.org/10.1016/S2468-2667(17)30045-2.

Greenhalgh, E. and Bayly, M. 2018. 'Prevalence of smoking: Adults.' In M. Scollo and M. Winstanley (eds), Tobacco in Australia: Facts and issues. Melbourne: Cancer Council Victoria.

Greenhalgh, E. and Scollo, M. 2018. 'Smoking and social disadvantage.' In M. Scollo and M. Winstanley (eds), Tobacco in Australia: Facts and issues. Melbourne: Cancer Council Victoria.

Greenhalgh, E., Bayly, M. and Winstanley, M. 2018. 'Prevalence of smoking: Adults.' In M. Scollo and M. Winstanley (eds), Tobacco in Australia: Facts and issues. Melbourne: Cancer Council Victoria.

Kelly, J., Maher, S. and Australian Associated Press 2011. 'Big tobacco to fight Rudd's cigarette plain packaging plan.' The Australian, 29 April. Available from: www. theaustralian.com.au/archive/politics/big-tobacco-to-fight-rudds-cigaretteplain-packaging-plan/news-story/edcb84582d8b4bb5d90074cce37b5a6d. 
Kickbusch, I., Allen, L. and Franz, C. 2016. 'The commercial determinants of health.' The Lancet: Global Health 4: e895-e896. doi.org/10.1016/S2214109X(16)30217-0.

Liberman, J. 2013. 'Plainly constitutional: The upholding of plain tobacco packaging by the High Court of Australia.' American Journal of Law \& Medicine 39: 361-81. doi.org/10.1177/009885881303900209.

Lloyd, P. 2010. 'The tobacco files.' Lateline, 10 September. Available from: www. abc.net.au/lateline/the-tobacco-files/2256476.

McKee, M. 2017. 'The tobacco industry: The pioneer of fake news.' Journal of Public Health Research 6(1). doi.org/10.4081/jphr.2017.878.

McLeod, K., Wakefield, M., Chapman, S., Smith, K. C. and Durkin, S. 2009. 'Changes in the news representation of smokers and tobacco-related media advocacy from 1995 to 2005 in Australia.' Journal of Epidemiology and Community Health 63: 215-20. doi.org/10.1136/jech.2007.072587.

Moodie, A. R., Carnell, K., Connors, C. and Larkin, S. 2008. 'Australia: The healthiest country by 2020.' Medical Journal of Australia 189: 588-90.

National Preventative Health Taskforce 2009. Australia: The healthiest country by 2020 - National preventative health strategy: The roadmap for action. Canberra: Commonwealth of Australia.

Parliament of Australia 1995. Report of the Senate Community Affairs Reference Committee: The tobacco industry and the costs of tobacco-related illness. Canberra: Parliament of Australia.

Parliament of Australia 2011. House of Representatives, Hansard, No. 18, 21 November: 12913. Canberra: Parliament of Australia.

Quit Victoria 2011. Tobacco industry persuades people to support plain packaging of cigarettes. Media release, [Online], 3 March. Melbourne: Quit Victoria. Accessed from: www.quit.org.au/media/article.aspx?ContentID=27_mar_ 201103 (site discontinued).

Scollo, M. 2012. 'Introduction.' In M. Scollo and M. Winstanley (eds), Tobacco in Australia: Facts and issues. Melbourne: Cancer Council Victoria. Available from: www.tobaccoinaustralia.org.au/introduction.

Scollo, M., Freeman, B. and Greenhalgh, E. 2016. 'Packaging as promotion.' In M. Scollo and M. Winstanley (eds), Tobacco in Australia: Facts and issues. Melbourne: Cancer Council Victoria. 
Siegel, M. 2013. 'Law spoils tobacco's taste, Australians say.' [Online]. The New York Times, 10 July. Available from: www.nytimes.com/2013/07/11/business/ global/law-spoils-tobaccos-taste-australians-say.html?_r=0.

Tobacco Working Group 2009. Tobacco in Australia: Making smoking history. Technical Report No. 2. Canberra: National Preventative Health Taskforce. Available from: content.webarchive.nla.gov.au/gov/wayback/201609230 60300/http:/www.preventativehealth.org.au/internet/preventativehealth/ publishing.nsf/Content/tech-tobacco.

Voon, T. and Mitchell, A. 2011. 'Face off: Assessing WTO challenges to Australia's scheme for plain tobacco packaging.' Public Law Review 22: 218-36.

Wakefield, M., Coomber, K., Zacher, M., Durkin, S., Brennan, E. and Scollo, M. 2015. 'Australian adult smokers' responses to plain packaging with larger graphic health warnings 1 year after implementation: Results from a national cross-sectional tracking survey.' Tobacco Control 24: ii17-ii25. doi.org/10.1136/tobaccocontrol-2014-052050.

White, V., Williams, T. and Wakefield, M. 2015. 'Has the introduction of plain packaging with larger graphic health warnings changed adolescents' perceptions of cigarette packs and brands?' Tobacco Control 24: ii42-ii49. doi.org/10.1136/tobaccocontrol-2014-052084.

World Health Organization (WHO) 2005. WHO Framework Convention on Tobacco Control. [Online]. Geneva: WHO. Available from: apps.who.int/iris/ bitstream/10665/42811/1/9241591013.pdf?ua=1.

World Health Organization (WHO) 2016. 'Posters: Get ready for plain packaging.' In World No Tobacco Day, 31 May. Geneva: WHO. Available from: www.who.int/campaigns/no-tobacco-day/2016/posters/en/.

World Health Organization (WHO) 2017a. Parties to the WHO Framework Convention on Tobacco Control. [Online]. 23 November. Geneva: WHO. Available from: www.who.int/fctc/signatories_parties/en/.

World Health Organization (WHO) 2017b. Tobacco Free Initiative. [Online]. Geneva: WHO. Available from: www.who.int/tobacco/mpower/publications/ en/.

Young, J. M., Stacey, I., Dobbins, T. A., Dunlop, S., Dessaix, A. L. and Currow, D. C. 2014. 'Association between tobacco plain packaging and Quitline calls: A population-based, interrupted time-series analysis.' Medical Journal of Australia 200: 29-32. doi.org/10.5694/mja13.11070. 
This text is taken from Successful Public Policy: Lessons from Australia and New Zealand, edited by Joannah Luetjens, Michael Mintrom and Paul 't Hart, published 2019 by ANU Press, The Australian National University, Canberra, Australia.

doi.org/10.22459/SPP.2019.13 